\title{
EVALUATION OF MICROBIAL LOAD IN SOME CANNED FRUITS AND LINE PROCESSING OF CANNED ORANGE
}

\author{
Ainan A. Shokr, Nahed A. El-Wafai, G.M. Mohamed and S.A.M. Mahgoub* \\ Agric. Microbiol. Dept., Fac. Agric., Zagazig Univ., Egypt
}

\begin{abstract}
The aim of this study was to evaluate the microbial load in lines producing canned orange at local plant. In addition, this study was conducted to give information about the quality (i.e., total viable count (TVC) and total yeasts and molds (TYM)), hygiene (coliforms and Clostridium spp.) and safety (i.e., Staphylococcus aureus and Escherichia coli) of some canned fruits kept on the shelf in markets. The final products of canned orange, grapefruit, peach, pineapple, cocktail and cherry had some TVC and TYM. The counts of these microbial populations ranged between 1.43 to $2.40 \log \mathrm{cfu} / \mathrm{g}$ and 1.0 to $1.85 \mathrm{log} \mathrm{cfu} / \mathrm{g}$, respectively. Clostridium spp., Staph. aureus and E. coli were totally absent in all canned fruits. The majority of the sampling sites examined were moderately contaminated (1.0 to 2.21 $\log \mathrm{cfu} / \mathrm{g}$ or $\mathrm{ml}$ or $\mathrm{cm}^{2}$ or can) by spoilage bacteria (coliforms, Bacillus spp. Staphylococci, Pseudomonas spp., and other bacteria) and fungi (Penicillium, Aspergillus spp. and other fungi) by workers, tables, water and peeling machines. The presence of this flora seemed to be associated with high numbers of one or more specific groups of the house-flora on the sampling sites and personal hands that as source of contamination. These findings further indicate that inadequate hygiene practices within processing line may result in loss of microbial control. It was shown that the hygienic status of the processing environment and equipment play an essential role in the microbial stability and safety of the final products.
\end{abstract}

Key words: Microbial quality, canning, orange, hygiene, safety.

\section{INTRODCTION}

Concentrated fruit products have a significant place in modern consumption markets and are valuable semi-prepared food components to the bakery, dairy, confectionary, canning, baby food, frozen food, distilling and beverage industries. There is continuous pressure on the beverage industry to improve the quality of concentrated fruit products in order to reconstituted fruit beverages to compete with beverages that are made from fresh fruits (Steyn et al., 2011; Ababouch, 2014). Several fruitprocessing plants have begun to utilize a program called the Hazard Analysis and Critical Control Point (HACCP) system to reduce pathogenic contamination and to reduce risks in food preparation to a safe level. This program

\footnotetext{
*Corresponding author: Tel. : +201099341197

E-mail address: mahgoubsamir@gmail.com
}

identifies the steps in the conversion of livestock to human food where the product is at risk of contamination by microorganisms (Anonymous, 2006). Having an effective HACCP program in place is mandatory in many areas of food production, including the production of low-acid canned foods, acidic, acidified foods and fruit juices. Although quality control methods are important to monitor quality and ensure that a consistently good product is supplied to the consumer, they do nothing to prevent hazards from occurring. Traditional HACCP is focused only on the health safety issues of a product and not the quality of the product, but HACCP principles are often applied to food quality assurance programs (Featherstone, $2015 \mathrm{a}$ and b).

Fresh product is an important part of a healthy diet. Its consumption was known to have 
health protective effects against a range of illnesses and health problems such as cancers and cardiovascular diseases. Consumers express their concerns about the food safety of fresh fruits, vegetables and fresh-cut products based on factors such as natural contaminants, agrochemicals, veterinary drugs and packaging materials. However, bacterial pathogens that cause decay/ spoilage are considered, overall, to represent the most important food safety issue of fresh produce, followed by foodborne viruses, pesticide residues and mycotoxins (Fallik, 2014). Spoilage in canned food is usually indicated by leakage, a swelling of container, or an abnormal thermostable toxin which will not be significantly affected by thermal process and will cause food poisoning. Therefore, the aim of this study was to 1) evaluate the microbial load on food contact surfaces and products during production line of canned orange fruit and hygienic status of one food factory located in ElSharkia Governorate, Egypt during the seasons and 2) give an information about the quality, hygiene and safety of some canned fruits during their shelf life.

\section{MATERIALS AND METHODS}

\section{Procurement of Samples}

The canned fruit samples were purchased from markets in Zagazig City, these included 3 cans of each canned product (i.e., peach, pineapple, cocktail and cherry). In addition, the canned orange (20 samples) and grapefruit (20 samples) were collected from local manufacture of canned fruit at El-Sharkia Governorate, Egypt.

\section{Manufacturing of Canned Fruits by Local Manufacture (Case Study)}

Canned orange was manufactured in a private fruit processing plant in Governorate of El-Sharkia, Egypt. The samples for microbiological examination were taken according to the scheme in the diagram in Fig. 1 along the processing lines during 2010 and 2011 seasons.

\section{Sampling Procedure}

Samples were collected at 6 different stages of canned orange fruit in a fruit processing plant, namely, segmenting line, peeling line, filling tank, chemical treatments, sugar tank samples and final products after pasteurization. In addition, samples were collected from equipment surfaces, personnel hands, cans and water samples (entry, Sheller, boiler and softener). The samples of peeling fruits and sugar solution were taken just prior to use for production.

Fruit samples were taken just after each process [peeling stage, segmenting stage, separation of seeds and white membrane, addition of sugar syrup (critical control point) and pasteurizing stage (critical control point)]. All peeling, water, sugar, and final product samples were taken from the same runs. Samples from the surfaces of equipment and tables were taken at the end of the work day after cleaning and sanitizing. The samples from the personnel hands were taken during working hours.

Ten grams of homogenous peeled fruits with sugar solution were taken and serial dilutions were carried out as well as final products were sampled aseptically using sterile knives and spoons for microbiological analyses. All samples were diluted up to $10^{-7}$ with sterile $0.1 \%$ $(W / V)$ saline peptone water (Anonymous, 1992).

Water samples (entry, Sheller, boiler and softener) of $10 \mathrm{ml}$ were taken using sterile pipettes and diluted up to $10^{-7}$ with sterile saline peptone water (Anonymous, 1992).

Swabs samples, from personnel hands and equipment surfaces were collected by the swab method. A sterile paper template was used to outline a $10 \mathrm{~cm}^{2}$ area, inside which a premoistened swab in $10 \mathrm{ml}$ sterile saline peptone water performed the swabbing, shaken, and squeezed in the diluents, and the rinse fluid plated in appropriate culture media.

All samples were immediately transferred to the laboratory in the same plant and analyzed. The results were expressed as means of replicates and expressed as log cfu.

\section{Microbiological Analysis}

Tenfold serial dilution was aseptically carried out and an aliquot inoculated onto sterile solidified agar in sterile Petri dishes using pour plate method of Cheesbrough (1994). Pure cultures 


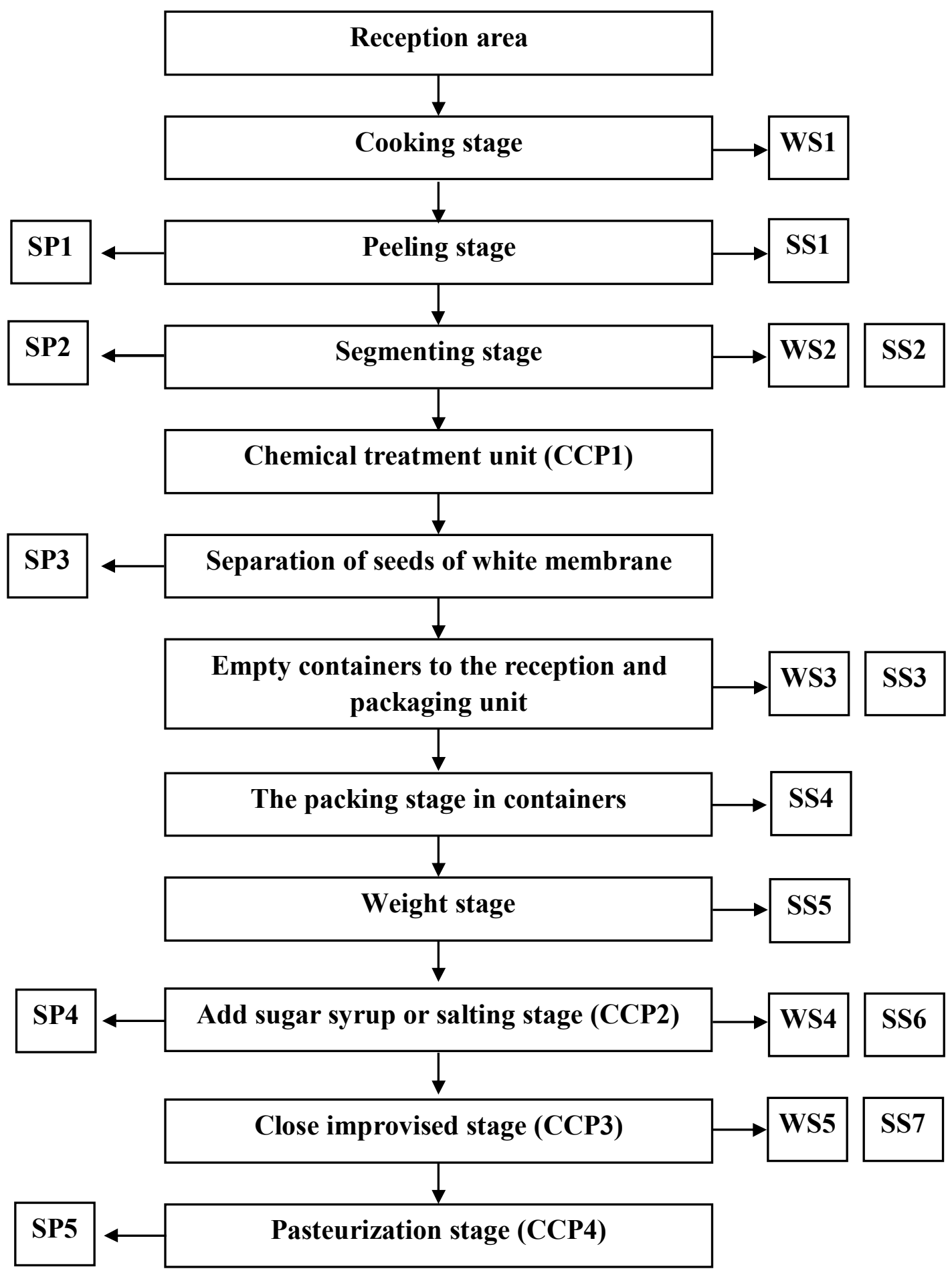

Fig. 1. The diagram of canned orange and sampling points 
were thereafter obtained by streaking. Gram reactions of the bacterial isolates were determined, followed by biochemical tests for identification of probable isolates carried out as described in Berger's Manual of Determinative Bacteriology (Holt, 1994).

Total Viable Count (TVC) was determined by the pour plate method on Plate Count Agar (PCA, Oxoid CM0463B, Hampshire, England). Plates were incubated at $35^{\circ} \mathrm{C}$ for $48 \mathrm{hr}$., (Anonymous, 1998). Yeast-molds were enumerated with Sabouraud Dextrose Agar (Merck, Darmstadt, Germany). Petri dishes were incubated at $25^{\circ} \mathrm{C}$ for 5 days for yeast and mold. The presence of Escherichia coli was examined by transferring $1 \mathrm{ml}$ of each dilution to sterile petri dishes followed by pouring $10 \mathrm{ml}$ of Violet Red Bile Agar (VRBA Oxoid, Hampshire, England) tempered at $45^{\circ} \mathrm{C}$ into plates. The plates were swirled, allowed to solidify, overlaid with 5-7 ml of VRBA and then incubated at $35^{\circ} \mathrm{C}$ for $18-24 \mathrm{hr}$. These plates were examined under long wavelength UV lamb for the presence of fluorescent colonies. Fluorescent colonies were enumerated as E. coli and all colonies were enumerated as total coliform (Anonymous, 1998). Enumeration of Staphylococcus aureus was performed by the spread plate method on Baird Parker Agar (Biolife, Milano, Italy). Plates were incubated at $35^{\circ} \mathrm{C}$ for $48 \mathrm{hr}$. Typical Staph. aureus colonies were examined and coagulase test was performed to these colonies (Anonymous, 1998). Petri dishes containing 30-300 colonies were enumerated (Anonymous, 1998). All microbial counts were expressed as base-10 logarithms of colony forming units per gram or milliliter or $\mathrm{cm}^{2}\left(\log \mathrm{cfu} / \mathrm{g}\right.$ or $\mathrm{ml}$ or $\left.\mathrm{cm}^{2}\right)$. The presence of Clostridium spp. was detected according to Garcia (2010). In brief, the samples were transferred to a 50-ml conical tube containing $20 \mathrm{ml}$ of distilled water and heatshocked for $5 \mathrm{~min}$ at $80^{\circ} \mathrm{C}$ to induce spore germination. For culturing of bacteria, $10 \mathrm{ml}$ of the distilled water were transferred into $100 \mathrm{ml}$ each of Trypticase-peptone-glucose-yeast extract (TPGY) and cooked meat medium (CMM) and incubated at $37^{\circ} \mathrm{C}$ for $72 \mathrm{hr}$.

\section{Statistical Analyses}

Sampling procedure was repeated 3 times at different production days with the intervals production. Means and standard deviation were calculated by Microsoft Excel 2010 (Snedecor and Cochran, 1980). The significant differences between the means of microbial counts at different stages of canning fruits processing were analyzed by the t-test (paired comparison) using MINITAB program (version 13.0).

\section{RESULTS AND DISCUSSION}

\section{Microbial Load in Canned Fruits at Markets During Their Shelf Life}

As the effect of microorganisms on human health has always been reported, the current study was conducted to give information about the quality (i.e., total bacteria and total yeasts and molds), hygiene (coliforms and Clostridium spp.) and safety (i.e., Staph. aureus and E. coli) of some canned fruits products kept on the shelf in markets.

The data in Table 1 delineate the distribution of total viable count (TVC), total yeasts and molds count (TYM), coliforms, Clostridium spp., Staph. aureus and E. coli in finished products of canned fruits i.e., orange, grapefruit, peach, pineapple, cocktail and cherry. The TVC was detected up to the level of $1.43-2.40 \mathrm{log}$ $\mathrm{cfu} / \mathrm{g}$. The load of TYM was counted to the level of $1.0-1.85 \log \mathrm{cfu} / \mathrm{g}$. The TVC and TYM groups were counted and detected in $100 \%$ of all samples. The highest number of TVC and TYM were detected in canned cocktail. However, coliforms, Clostridium spp., Staph. aureus and $E$. coli were totally absent in all canned fruit samples. Canned foods are sterilized before being placed on the grocery shelf but if the sterilization has been unsuccessful, contamination or food spoilage may occur (Desrosier and Desrosier, 2004). Therefore, the plant environment, canning and good practice storage may be unfavorable to the persistence and growth of the aforementioned bacteria. Several fruit-processing plants have begun to utilize a program called HACCP system to reduce pathogenic contamination. This program identifies the steps in the conversion of livestock to human food where the product is at risk of contamination by microorganisms (Anonymous, 2006). Having an effective HACCP program in place is mandatory in many areas of food production, including the production of low-acid 
Table 1. Total viable count (TVC), total yeasts and molds count (TYM), coliforms, Clostridium spp., Staphylococcus aureus and Escherichia coli $(\log \mathrm{cfu} / \mathrm{g} \pm \mathrm{SD})$ in finished products of canned fruits

\begin{tabular}{|c|c|c|c|c|c|c|}
\hline \multirow[t]{2}{*}{ Canned fruit } & \multicolumn{2}{|c|}{ Quality } & \multicolumn{2}{|c|}{ Hygiene } & \multicolumn{2}{|c|}{ Safety } \\
\hline & TVC & TYM & Coliforms & Clostridium spp. & Staph. aureus & E. coli \\
\hline$\overline{\text { Orange }}$ & $1.57 \pm 0.04$ & $1.0 \pm 0.00$ & ve & ve & ve & ve \\
\hline Grapefruit & $1.69 \pm 0.05$ & $1.00 \pm 0.00$ & ve & - ve & - ve & ve \\
\hline Peach & $1.43 \pm 0.08$ & $1.00 \pm 0.01$ & ve & ve & - ve & ve \\
\hline Pineapple & $2.05 \pm 0.07$ & $1.18 \pm 0.04$ & - ve & ve & - ve & ve \\
\hline Cocktail & $2.40 \pm 0.05$ & $1.85 \pm 0.05$ & - ve & - ve & - ve & ve \\
\hline Cherry & $2.14 \pm 0.04$ & $1.62 \pm 0.08$ & ve & ve & - ve & ve \\
\hline
\end{tabular}

ve, the result is negative.

canned foods, acidic, acidified foods and fruit juices (Featherstone, 2015b). Finished product testing therefore is useless process control and robust procedures for establishing the scheduled process are the only useful food safety management options (Zwietering et al., 2016). In this study, the TVC and TYM were at low levels of 1.43 and $1.0 \mathrm{log} \mathrm{cfu} / \mathrm{g}$, respectively. Based on their detailed characteristics and identification profiles (data not shown), the following genera and species of TVC isolated from various canned fruits were identified as spore forming rod-shaped bacteria (Bacillus spp.) The predominance of Bacillus spp. was possibly due to the presence of spores in the raw materials which may have survived cooking and pasteurization (Mosupye and Von Holy, 1999).

\section{Microbiological Quality, Hygiene and Safety in Local Canned Orange (Case Study)}

\section{Canned orange fruits along processing lines}

The sampling points were included peeling (SP1), segmenting (SP2), separation of seeds and white membrane (SP3), adding sugar syrup (SP4) and after pasteurization stages (SP5) samples. The distribution of total viable count (TVC), total yeasts and molds (TYM), coliforms, Clostridium spp., Staph aureus and E. coli in canned orange along processing lines are presented in Table 2. Generally, potential products safety and quality can be estimated with the use of indicator microorganisms including aerobic plate count and E. coli count. The mean count of coliforms in all sampling points ranged between 1.00-1.18 log cfu/g during November-December 2010 and MarchApril 2011. In the same period the samples were positive to E. coli. High E. coli generally correlate with the higher levels of food-borne pathogens originating from fecal origin and water (Jay, 1992). Also, the mean count of TVC and TYM ranged in the expected range (1.88 $2.21,1.72-2.14,1.54-1.88$ and $1.30-1.71 \log$ $\mathrm{cfu} / \mathrm{g})$ and $(1.37-1.55,1.22-1.40,1.08-1.21$ and $0.82-1.01 \log \mathrm{cfu} / \mathrm{g}$ ) in SP1, SP2, SP3 and SP4, respectively and under detection limit at SP5 (Table, 2). The counts in pasteurized orange were significantly $(\mathrm{P}<0.05)$ lower than those of peeled and separated fruits. In this study the highest microbial count was found in the cooking, peeling and separating stages in products. Clostridium spp., Staph. aureus and E. coli counts were under the detection limit after vacuumed and pasteurization stages in SP5. The heat resistant spores of sporeformer bacteria may survive pasteurization while vegetative bacteria were eliminated (Freire and Offord, 2003). After the addition of sugar syrup stage the orange were packed and closed in sterilized cans under vacuum and pasteurized at $85^{\circ} \mathrm{C}$ for $10 \mathrm{~min}$. The mean counts of TVC and yeast and molds counts in the current study is in line with Vantarakis et al. (2011) who reported that the counts of 125 colonies forming unit of total microbial 
Table 2. Total viable count (TVC), total yeasts and molds count (TYM), coliforms, Clostridium spp., Staphylococcus aureus and Escherichia coli $(\log$ cfu/g \pm SD) at different stages of canned orange in a fruit processing plant ${ }^{(1)}$

\begin{tabular}{|c|c|c|c|c|c|c|c|}
\hline \multirow{2}{*}{$\begin{array}{l}\text { Sampling } \\
\text { point (SP) }\end{array}$} & \multirow{2}{*}{$\begin{array}{c}\text { Time } \\
\text { (month) }\end{array}$} & \multicolumn{2}{|c|}{ Quality } & \multicolumn{2}{|c|}{ Hygiene } & \multicolumn{2}{|l|}{ Safety } \\
\hline & & TVC & TYM & Coliform & $\overline{\text { tridium }}$ & Staph. aureus & $\overline{E . c o l i}$ \\
\hline \multirow{3}{*}{ SP1 } & $11+12 / 2010$ & $2.21 \pm 0.02$ & $1.49 \pm 0.08$ & $1.18 \pm 0.02$ & ve & ve & $+\mathrm{ve}$ \\
\hline & $1+2 / 2011$ & $2.09 \pm 0.08$ & $1.55 \pm 0.02$ & $1.00 \pm 0.00$ & ve & -ve & ve \\
\hline & $3+4 / 2011$ & $1.88 \pm 0.04$ & $1.37 \pm 0.07$ & $1.00 \pm 0.00$ & ve & -ve & ve \\
\hline \multirow{3}{*}{ SP2 } & $11+12 / 2010$ & $2.14 \pm 0.09$ & $1.22 \pm 0.07$ & $1.00 \pm 0.00$ & ve & -ve & ve \\
\hline & $1+2 / 2011$ & $2.00 \pm 0.08$ & $1.40 \pm 0.03$ & $1.00 \pm 0.00$ & ve & -ve & -ve \\
\hline & $3+4 / 2011$ & $1.72 \pm 0.03$ & $1.25 \pm 0.04$ & $1.00 \pm 0.00$ & ve & -ve & $+\mathrm{ve}$ \\
\hline \multirow{3}{*}{ SP3 } & $11+12 / 2010$ & $1.76 \pm 0.04$ & $1.21 \pm 0.06$ & $1.00 \pm 0.00$ & ve & -ve & -ve \\
\hline & $1+2 / 2011$ & $1.88 \pm 0.08$ & $1.21 \pm 0.02$ & $1.00 \pm 0.00$ & ve & -ve & ve \\
\hline & $3+4 / 2011$ & $1.54 \pm 0.05$ & $1.08 \pm 0.04$ & $1.00 \pm 0.00$ & ve & -ve & -ve \\
\hline \multirow{3}{*}{ SP4 } & $11+12 / 2010$ & $1.30 \pm 0.04$ & $1.01 \pm 0.03$ & $1.00 \pm 0.00$ & ve & -ve & ve \\
\hline & $1+2 / 2011$ & $1.71 \pm 0.09$ & $1.01 \pm 0.04$ & $1.00 \pm 0.00$ & ve & -ve & ve \\
\hline & $3+4 / 2011$ & $1.31 \pm 0.03$ & $0.82 \pm 0.06$ & $1.00 \pm 0.00$ & -ve & -ve & ve \\
\hline \multirow{3}{*}{ SP5 } & $11+12 / 2010$ & $<1.00 \pm 0.0$ & $<1.00 \pm 0.0$ & $1.00 \pm 0.00$ & ve & -ve & ve \\
\hline & $1+2 / 2011$ & $<1.00 \pm 0.0$ & $<1.00 \pm 0.0$ & $1.00 \pm 0.00$ & ve & -ve & -ve \\
\hline & $3+4 / 2011$ & $<1.00 \pm 0.0$ & $<1.00 \pm 0.0$ & $1.00 \pm 0.00$ & ve & -ve & ve \\
\hline
\end{tabular}

(1) All values reflect the mean values of two months and 3 replicates and standard deviation, SP1: Peeling stage, SP2: Segmenting stage SP3: Separation of seeds, SP4: Add sugar syrup stage and SP5: Pasteurization stage. ( $(\mathrm{ve})$ : the result is positive and ( $\mathrm{ve}$ ) the result is negative.

count in packed fruits juices was detected. The International Commission on microbiological specification in foods recommended that orange fruits can be treated as a raw agricultural commodity with ultimate use of the product determining the acceptable microbial load (Omafuvbe and Kolawole, 2004). Total plate count and yeast-molds counts decreased after adding sugar syrup, but it was not detected after pasteurization. Borch et al. (1988) reported similar reduction in total plate count after cooking of the foods. This result is important to reveal the effectiveness of pasteurization on the inhibition of Staph. aureus that can survive or is present due to the contamination after cooking. Since coliforms, E. coli and yeast and mold were already inhibited due to chemical and pasteurization process, these microorganisms were not present after pasteurization. The counts of TVC, yeasts mold in product during processing line were found low in the microbiological standards of the EU Council (2003/1642/EC), Egyptian Food Codex for canning fruits and Food Standards Programme Codex Committee On Processed Fruits And Vegetables (FAO/WHO, 2012).

\section{Water used in processing of canned orange fruit}

Water used during cooking, cooling, solving sugar and cleaning could be contaminated with bacteria, molds, and yeasts. Microbial load of water depends on its quality and processing steps. So, the microbial load of the water used affected the microbial load of fruits. The mean count of TVC and TYM ranged between 2.13- 
1.94, 1.93-1.68, 1.74-1.45, and 1.78-1.55 log cfu/ml and 1.21-1.13, 1.21-1.06, 1.16-1.0 and $1.21-1.01 \log \mathrm{cfu} / \mathrm{ml}$ in entry (WS1), Sheller (WS2), boiler (WS3) and softener samples (WS4), respectively (Table 3 ). While the highest number of TVC was found in the entry samples $(2.13 \log \mathrm{cfu} / \mathrm{ml})$ while the lowest number of TVC was detected at a level of $1.45 \log \mathrm{cfu} / \mathrm{ml}$ in boiler samples. The dominant pathogen during the monsoon season was E. coli, which may have been due to the use of affected water (Tambekar et al., 2008). E. coli frequently contaminate food items and are often considered a good indicator of fecal pollution (Benkerroum et al., 2004). The highest count of coliforms was $1.48 \mathrm{log} \mathrm{cfu} / \mathrm{ml}$ in entry water samples and the lowest was $1.0 \log \mathrm{cfu} / \mathrm{ml}$ in boiler water samples. However, E. coli was not detected in all samples during the season of production except during November and December 2010 and from January to April 2011 it was detected as a positive in entry water samples. This result showed that microbial quality of water in the plant was appropriate for use in production. A major reason for this reduction in the microbial load of water is the addition of sugar into the slices of fruits. Contaminated cooling water sometimes leaks to the interior through pinholes or poor seams and introduces bacteria that cause spoilage. Laboratory studies have determined that berry juices and purées can support bacteria such as E. coli O157: $\mathrm{H} 7$ and Salmonella spp. (Zhao, 2005) and water used in food processing can be a carrier of pathogenic bacteria (e.g. $E$. coli, Salmonella spp., Vibrio cholera, Shigella spp.), protozoa (e.g. Cryp-tosporidium partum, Giardia lamblia, Cyclosporacayetanensis, Toxiplasmagondii), mycotoxin-producing fungi and viruses (e.g. Norwalk and hepatitis A) (Zhao, 2005). A major source of microbial infection is introduced through contaminated water used on fresh produce during growth, harvesting and processing.

\section{Swab samples of workers}

Data in Table 4 shows the microbial load of workers at different stages of canned orange in fruit processing plant. Staph. aureus was detected only in swabs of workers and personal hands during November- December 2010. One of the major risks of food contamination originates from the working practices of food handlers and disease-causing microorganisms present in or on the food handler's body which subsequently transported from the food handler to the food during the handling process (Gordon-Davis, 1998). The mean count of TVC and TYM ranged between 2.05-1.84, 2.04-1.87, $2.07-1.90,1.99-1.85,1.99-1.83$ and $1.97-1.86$ $\log \mathrm{cfu} / \mathrm{cm}^{2}$ and $1.29-1.01,1.12-1.01,1.05-1.02$, $1.02-1.02,1.13-1.02$ and $1.03-1.02 \mathrm{log} \mathrm{cfu} / \mathrm{cm}^{2}$ in SS1, SS2, SS3, SS4, SS5 and SS6 samples, respectively. Personnel hygiene is very important in food processing because the human is considered as a major source of contamination in food poisoning caused by Staph. aureus. Poor personal hygiene practices, such as negligence to wash hands after visiting the bathroom may result in up to $10^{7}$ pathogens under the fingernails of the food handler (Nel et al., 2004). The most probable reason of microbial count in canning fruits production line might be the poor hygienic quality of fresh fruits, inadequate storage and pasteurization and chemical treatments, contamination from personal hands, and the time between peeling and separation stages as well as the addition of sugar syrups. A Canning fruit poses more risk compared to whole fruits because it can be contaminated by personal hands, increased surface area, peeling, and separating seeds and mixing during the sugar syrups operation. Based on the poor air quality in the working environment of the processing line of orange or grapefruit and because many of these microorganisms can be acquired by the workers, either by inhalation, ingestion, or other means, some of the identified bacteria, in the indoor environment of canning were detected (Nel et al., 2004).

\section{Equipment surfaces in production line of canned orange fruits}

The results of microbial load of equipment surfaces are presented in Table 5. The total plate count and yeast-molds of equipment surfaces (segmenting line, collecting line, before can sterilization, sugar tank and before chemical treatment) were between $1.98-1.91,1.98-1.84$, $1.97-1.75,1.94-1.74$ and $1.88-1.64 \log \mathrm{cfu} / \mathrm{cm}^{2}$ and $1.35-1.10,1.17-1.12,1.27-1.18,1.28-1.02$ and 1.16-1.01 $\log \mathrm{cfu} / \mathrm{cm}^{2}$, respectively. The coliforms were detected only at segmenting line with a level of $1.48 \log \mathrm{cfu} / \mathrm{cm}^{2}$ during December 2010. However, Clostridium, Staph. aureus and E. coli were not found during all the rest of the season of production. Generally 
Table 3. Total viable count (TVC), total yeasts and molds count (TYM), coliforms, Clostridium spp., Staphylococcus aureus and Escherichia coli $(\log \mathrm{cfu} / \mathrm{g} \pm \mathrm{SD})$ in water samples at different stages of canned orange in a fruit processing plant ${ }^{(1)}$

\begin{tabular}{|c|c|c|c|c|c|c|c|}
\hline \multirow{2}{*}{$\begin{array}{c}\text { Water samples } \\
\text { (WS) }\end{array}$} & \multirow{2}{*}{$\begin{array}{c}\text { Time } \\
\text { (month) }\end{array}$} & \multicolumn{2}{|c|}{ Quality } & \multicolumn{2}{|c|}{ Hygiene } & \multicolumn{2}{|l|}{ Safety } \\
\hline & & TVC & TYM & Coliform & Clostridium & Staph. aureus & E. coli \\
\hline \multirow{3}{*}{$\begin{array}{c}\text { WS1 } \\
\text { (Entry) }\end{array}$} & $11+12 / 2010$ & $2.13 \pm 0.04$ & $1.21 \pm 0.01$ & $1.48 \pm 0.06$ & ve & ve & ${ }^{+}$ve \\
\hline & $1+2 / 2011$ & $2.01 \pm 0.01$ & $1.13 \pm 0.01$ & $1.00 \pm 0.00$ & ve & ve & ${ }^{+}$ve \\
\hline & $3+4 / 2011$ & $1.94 \pm 0.03$ & $1.21 \pm 0.01$ & $1.40 \pm 0.03$ & ve & ve & ${ }^{+}$ve \\
\hline \multirow{3}{*}{$\begin{array}{c}\text { WS2 } \\
\text { (Sheller) }\end{array}$} & $11+12 / 2010$ & $1.93 \pm 0.03$ & $1.19 \pm 0.01$ & $1.00 \pm 0.00$ & ve & ve & \\
\hline & $1+2 / 2011$ & $1.84 \pm 0.02$ & $1.06 \pm 0.02$ & $1.00 \pm 0.00$ & ve & ve & ve \\
\hline & $3+4 / 2011$ & $1.68 \pm 0.06$ & $1.12 \pm 0.05$ & $1.00 \pm 0.00$ & ve & ve & - ve \\
\hline \multirow{3}{*}{$\begin{array}{c}\text { WS3 } \\
\text { (Boiler) }\end{array}$} & $11+12 / 2010$ & $1.74 \pm 0.03$ & $1.16 \pm 0.03$ & $1.00 \pm 0.00$ & ve & ve & ve \\
\hline & $1+2 / 2011$ & $1.56 \pm 0.02$ & $1.00 \pm 0.00$ & $1.00 \pm 0.00$ & ve & ve & ve \\
\hline & $3+4 / 2011$ & $1.45 \pm 0.03$ & $1.00 \pm 0.00$ & $1.00 \pm 0.00$ & ve & ve & ve \\
\hline \multirow{3}{*}{$\begin{array}{c}\text { WS4 } \\
\text { (Softener) }\end{array}$} & $11+12 / 2010$ & $1.78 \pm 0.05$ & $1.18 \pm 0.03$ & $1.0 \pm 0.000$ & ve & ve & ve \\
\hline & $1+2 / 2011$ & $1.61 \pm 0.03$ & $1.01 \pm 0.01$ & $1.00 \pm 0.00$ & ve & ve & ve \\
\hline & $3+4 / 2011$ & $1.55 \pm 0.02$ & $1.21 \pm 0.03$ & $1.00 \pm 0.00$ & ve & ve & ve \\
\hline
\end{tabular}

(1)All values reflect the mean values of two months and 3 replicates with standard deviation, $\left.{ }^{+}{ }^{+} v\right)$ the result is positive and ( $\mathrm{ve}$ ) the result is negative.

Table 4. Total viable count (TVC), total yeasts and molds count (TYM), coliforms, Clostridium spp., Staphylococcus aureus and Escherichia coli $(\log \mathrm{cfu} / \mathrm{g} \pm \mathrm{SD})$ in swabs of workers at different stages of canned orange in a fruit processing plant ${ }^{(1)}$

\begin{tabular}{|c|c|c|c|c|c|c|c|}
\hline \multirow{2}{*}{$\begin{array}{l}\text { Swabs samples } \\
\text { of workers (SS) }\end{array}$} & \multirow{2}{*}{$\begin{array}{c}\text { Time } \\
\text { (month) }\end{array}$} & \multicolumn{2}{|c|}{ Quality } & \multicolumn{2}{|c|}{ Hygiene } & \multicolumn{2}{|l|}{ Safety } \\
\hline & & TVC & TYM & Coliform & Clostridium & Staph. aureus & E. coli \\
\hline \multirow{3}{*}{ SS1 } & $11+12 / 2010$ & $2.05 \pm 0.00$ & $1.29 \pm 0.00$ & $1.48 \pm 0.00$ & ve & ve & ${ }^{+}$ve \\
\hline & $1+2 / 2011$ & $1.94 \pm 0.00$ & $1.01 \pm 0.00$ & $1.00 \pm 0.00$ & ve & ve & ve \\
\hline & $3+4 / 2011$ & $1.84 \pm 0.00$ & $1.09 \pm 0.00$ & $1.40 \pm 0.00$ & ve & ve & ve \\
\hline \multirow{3}{*}{ SS2 } & $11+12 / 2010$ & $2.04 \pm 0.00$ & $1.10 \pm 0.00$ & $1.00 \pm 0.00$ & ve & ve & ve \\
\hline & $1+2 / 2011$ & $1.93 \pm 0.00$ & $1.01 \pm 0.00$ & $1.00 \pm 0.00$ & ve & ve & ve \\
\hline & $3+4 / 2011$ & $1.87 \pm 0.00$ & $1.12 \pm 0.00$ & $1.00 \pm 0.00$ & ve & ve & ve \\
\hline \multirow{3}{*}{ SS3 } & $11+12 / 2010$ & $2.07 \pm 0.00$ & $1.02 \pm 0.00$ & $1.00 \pm 0.00$ & ve & ve & ve \\
\hline & $1+2 / 2011$ & $1.93 \pm 0.00$ & $1.05 \pm 0.00$ & $1.00 \pm 0.00$ & ve & ve & ve \\
\hline & $3+4 / 2011$ & $1.90 \pm 0.00$ & $1.02 \pm 0.00$ & $1.00 \pm 0.00$ & ve & ve & ve \\
\hline \multirow{3}{*}{ SS4 } & $11+12 / 2010$ & $1.99 \pm 0.00$ & $1.02 \pm 0.00$ & $1.00 \pm 0.00$ & ve & ve & ve \\
\hline & $1+2 / 2011$ & $1.95 \pm 0.00$ & $1.02 \pm 0.00$ & $1.00 \pm 0.00$ & ve & ve & ve \\
\hline & $3+4 / 2011$ & $1.85 \pm 0.00$ & $1.02 \pm 0.00$ & $1.00 \pm 0.00$ & ve & ve & ve \\
\hline \multirow{3}{*}{ SS5 } & $11+12 / 2010$ & $1.99 \pm 0.00$ & $1.05 \pm 0.00$ & $1.00 \pm 0.00$ & ve & ve & ve \\
\hline & $1+2 / 2011$ & $1.88 \pm 0.00$ & $1.13 \pm 0.00$ & $1.00 \pm 0.00$ & ve & ve & ve \\
\hline & $3+4 / 2011$ & $1.83 \pm 0.00$ & $1.02 \pm 0.00$ & $1.00 \pm 0.00$ & ve & ve & ve \\
\hline \multirow{3}{*}{ SS6 } & $11+12 / 2010$ & $1.97 \pm 0.00$ & $1.03 \pm 0.00$ & $1.00 \pm 0.00$ & ve & ve & ve \\
\hline & $1+2 / 2011$ & $1.90 \pm 0.00$ & $1.02 \pm 0.00$ & $1.00 \pm 0.00$ & ve & ve & ve \\
\hline & $3+4 / 2011$ & $1.86 \pm 0.00$ & $1.02 \pm 0.00$ & $1.00 \pm 0.00$ & ve & ve & ve \\
\hline
\end{tabular}

(1) All values reflect the mean values of two months and 3 replicates with standard deviation, $\left({ }^{+} \mathrm{ve}\right)$ : the results is positive and (ve) the results is negative. 
Table 5. Total viable count (TVC), total yeasts and molds count (TYM), coliforms, Clostridium spp., Staphylococcus aureus and Escherichia coli (log cfu/g \pm SD) in equipment samples at different stages of canned orange in a fruit processing plant ${ }^{(1)}$

\begin{tabular}{|c|c|c|c|c|c|c|c|}
\hline \multirow{2}{*}{$\begin{array}{l}\text { Equipment } \\
\text { samples }\end{array}$} & \multirow{2}{*}{$\begin{array}{c}\text { Time } \\
\text { (month) }\end{array}$} & \multicolumn{2}{|c|}{ Quality } & \multicolumn{2}{|c|}{ Hygiene } & \multicolumn{2}{|l|}{ Safety } \\
\hline & & TVC & TYM & $\overline{C F}$ & Clostridium & Staph. aureus & $\bar{E}$. coli \\
\hline \multirow{3}{*}{$\begin{array}{l}\text { Segmenting } \\
\text { line }\end{array}$} & $11+12 / 2010$ & $1.98 \pm 0.12$ & $1.19 \pm 0.09$ & $1.48 \pm 0.05$ & ve & ve & ve \\
\hline & $1+2 / 2011$ & $1.95 \pm 0.22$ & $1.10 \pm 0.05$ & $1.00 \pm 0.02$ & ve & ve & ve \\
\hline & $3+4 / 2011$ & $1.91 \pm 0.42$ & $1.35 \pm 0.07$ & $1.40 \pm 0.03$ & ve & ve & ve \\
\hline \multirow{3}{*}{$\begin{array}{l}\text { Collecting } \\
\text { line }\end{array}$} & $11+12 / 2010$ & $1.98 \pm 0.62$ & $1.13 \pm 0.05$ & $1.00 \pm 0.07$ & ve & ve & ve \\
\hline & $1+2 / 2011$ & $1.86 \pm 0.32$ & $1.12 \pm 0.08$ & $1.00 \pm 0.00$ & ve & ve & ve \\
\hline & $3+4 / 2011$ & $1.84 \pm 0.12$ & $1.17 \pm 0.05$ & $1.00 \pm 0.00$ & ve & ve & ve \\
\hline \multirow{3}{*}{$\begin{array}{c}\text { Before can } \\
\text { sterilization }\end{array}$} & $11+12 / 2010$ & $1.97 \pm 0.08$ & $1.18 \pm 0.07$ & $1.00 \pm 0.00$ & ve & ve & ve \\
\hline & $1+2 / 2011$ & $1.76 \pm 0.07$ & $1.07 \pm 0.09$ & $1.00 \pm 0.00$ & ve & ve & ve \\
\hline & $3+4 / 2011$ & $1.75 \pm 0.06$ & $1.27 \pm 0.05$ & $1.00 \pm 0.00$ & ve & ve & ve \\
\hline \multirow{3}{*}{ Sugar tank } & $11+12 / 2010$ & $1.94 \pm 0.05$ & $1.28 \pm 0.21$ & $1.00 \pm 0.00$ & ve & ve & ve \\
\hline & $1+2 / 2011$ & $1.76 \pm 0.01$ & $1.06 \pm 0.32$ & $1.00 \pm 0.00$ & ve & ve & ve \\
\hline & $3+4 / 2011$ & $1.74 \pm 0.02$ & $1.02 \pm 0.02$ & $1.00 \pm 0.02$ & ve & ve & ve \\
\hline \multirow{3}{*}{$\begin{array}{l}\text { Before } \\
\text { chemical } \\
\text { treatment }\end{array}$} & $11+12 / 2010$ & $1.88 \pm 0.02$ & $1.04 \pm 0.02$ & $1.00 \pm 0.02$ & ve & ve & ve \\
\hline & $1+2 / 2011$ & $1.82 \pm 0.02$ & $1.16 \pm 0.02$ & $1.00 \pm 0.02$ & ve & ve & ve \\
\hline & $3+4 / 2011$ & $1.64 \pm 0.02$ & $1.01 \pm 0.02$ & $1.00 \pm 0.02$ & ve & ve & ve \\
\hline
\end{tabular}

(1) All values reflect the mean values of two months and 3 replicates with standard deviation, ( $\mathrm{ve}$ ) the result is negative.

microbial load of equipment surfaces depends on microbial quality of food, cleaning and sanitation program in the plant (Nortjé et al., 1989).

Table 6 shows the microbial load of can samples of canning fruits. The mean count of TVC and TYM ranged between 1.20 to $0.63 \mathrm{log}$ $\mathrm{cfu} / \mathrm{can}$ and 1.01 to $0.45 \log \mathrm{cfu} / \mathrm{can}$ in 4 cans, respectively. However, all other microbial groups were absent in all examined cans during the period of study.

\section{Bacteria and yeast-mold population} analyses and characterization

In this study, the characterization of the bacteria present in production line of canned orange fruits revealed the presence of Staph. aureus in workers employees, whereas the bacteria identified in the control group corresponded to normal flora. The most frequently identified bacteria were coliform, which was also present in the air. Fungi were also identified by microscopy and these included Aspergillus and Penicillium which are considered the airborne allergenic fungi most significant and found to be associated with adverse effects on human and animal health (Cooke, 1996; Özdilli et al., 2007). The presence of this flora seemed to be associated with high numbers of one or more specific groups of the house-flora on the sampling sites and personnel hands as secondary contamination. With regard to product samples, fresh orange was contaminated with the houseflora present on surfaces and equipment of the processing lines.

Microbial counts in personnel hands and equipment showed significant correlations with the counts in products of the samples taken from all processing stages (Table 7). 
Table 6. Total viable count (TVC), total yeasts and molds count (TYM), coliforms, Clostridium spp., Staphylococcus aureus and Escherichia coli $(\log \mathrm{cfu} / \mathrm{g} \pm \mathrm{SD})$ in cans of canned orange in a fruit processing plant ${ }^{(1)}$

\begin{tabular}{|c|c|c|c|c|c|c|c|}
\hline \multirow[t]{2}{*}{ Samples } & \multirow{2}{*}{$\begin{array}{c}\text { Time } \\
\text { (month) }\end{array}$} & \multicolumn{2}{|c|}{ Quality } & \multicolumn{2}{|c|}{ Hygiene } & \multicolumn{2}{|c|}{ Safety } \\
\hline & & TVC & TYM & Coliform & Clostridium & Staph. aureus & E. coli \\
\hline \multirow{3}{*}{ Can1 } & $11+12 / 2010$ & $1.10 \pm 0.04$ & $0.69 \pm 0.04$ & ve & ve & ve & ve \\
\hline & $1+2 / 2011$ & $1.09 \pm 0.07$ & $0.79 \pm 0.03$ & ve & - ve & - ve & - ve \\
\hline & $3+4 / 2011$ & $1.20 \pm 0.06$ & $1.01 \pm 0.01$ & ve & - ve & - ve & ve \\
\hline \multirow{3}{*}{ Can2 } & $11+12 / 2010$ & $0.93 \pm 0.05$ & $0.45 \pm 0.01$ & ve & ve & ve & ve \\
\hline & $1+2 / 2011$ & $1.07 \pm 0.03$ & $0.59 \pm 0.02$ & - ve & ve & - ve & - ve \\
\hline & $3+4 / 2011$ & $1.10 \pm 0.03$ & $0.81 \pm 0.06$ & ve & - ve & - ve & ve \\
\hline \multirow{3}{*}{ Can3 } & $11+12 / 2010$ & $0.63 \pm 0.04$ & $0.46 \pm 0.02$ & ve & ve & ve & ve \\
\hline & $1+2 / 2011$ & $0.72 \pm 0.04$ & $0.49 \pm 0.02$ & ve & ve & ve & ve \\
\hline & $3+4 / 2011$ & $1.01 \pm 0.09$ & $0.66 \pm 0.03$ & ve & - ve & ve & ve \\
\hline \multirow{3}{*}{ Can4 } & $11+12 / 2010$ & $0.93 \pm 0.08$ & $0.45 \pm 0.03$ & ve & - ve & ve & ve \\
\hline & $1+2 / 2011$ & $1.07 \pm 0.07$ & $0.59 \pm 0.07$ & ve & ve & ve & ve \\
\hline & $3+4 / 2011$ & $1.10 \pm 0.06$ & $0.81 \pm 0.05$ & - ve & - ve & ve & ve \\
\hline
\end{tabular}

(1) All values reflect the mean values of two months and 3 replicates with standard deviation, (ve) the result is negative

Table 7. Correlation between the counts in products of the samples taken from all processing stages of orange fruits

\begin{tabular}{|c|c|c|c|c|c|c|c|}
\hline \multirow[t]{2}{*}{ Samples } & & \multicolumn{2}{|c|}{ Canned orange } & Water & Workers & \multicolumn{2}{|c|}{$\begin{array}{ll}\text { Equipment } & \text { Cans }\end{array}$} \\
\hline & & TVC & TYM & TVC TYM & TVC TYM & $\overline{\text { TVC TYM }}$ & $\overline{\text { TVC TYM }}$ \\
\hline \multirow{2}{*}{ Canned orange } & TVC & & & & & & \\
\hline & TYM & & & & & & \\
\hline \multirow{2}{*}{ Water } & TVC & $0.7^{*}$ & & & & & \\
\hline & TYM & & -0.1 & & & & \\
\hline \multirow{2}{*}{ Workers } & TVC & -0.06 & & -0.6 & & & \\
\hline & TYM & & -0.03 & -0.7 & & & \\
\hline \multirow{2}{*}{ Equipment } & TVC & $0.8^{*}$ & & -0.5 & 0.4 & & \\
\hline & TYM & & $0.7 *$ & -0.4 & 0.3 & & \\
\hline \multirow{2}{*}{ Cans } & TVC & -0.4 & & -0.8 & -0.9 & -0.7 & \\
\hline & TYM & & -0.3 & -0.4 & -0.2 & -0.5 & \\
\hline
\end{tabular}

*P $<0.05$ 
There was a correlation between coliforms and E. coli as well as there was positive correlation $(\mathrm{r}=0.70)$ between final products and water. High microbial count causes an increase in the microbial count of the product at processing stages. This result has confirmed this assertion. There was a positive correlation for the presence of TVC $(\mathrm{r}=0.8)$ and for TYM $(\mathrm{r}=0.7)$ between the final product and equipment surface (Table 7).

\section{Conclusion}

According to the previous results, environmental process was found to be the primary contamination sources. Equipment surfaces and personnel hands were determined as the secondary contamination sources. Microbial counts in personnel hands and equipment showed significant correlations with the counts in products of the samples taken from all processing stages. Microorganism counts determined in overall processing were not at harmful levels for human health and the microbial load of the final product was within the critical limits.

\section{REFERENCES}

Ababouch, L. (2014). Heat Treatment of Foods Spoilage Problems Associated With Canning. Encyclopedia of Food Microbiol. $2^{\text {nd }}$ Ed., 175-180.

Anonymous (1992). Compendium of Methods for the Microbiological Examination of Foods. In: Vanderzant, C., Splittstoesser, D.F., Eds., $3^{\text {rd }}$ Ed., Am. Publican Health Ass., Washington D.C. USA.

Anonymous (1998). Food and Drug Administration Bacteriological Analytical Manual. $8^{\text {th }}$ Ed., Revision Gaithersburg, A. USA.

Anonymous (2006). Meat Processing. Encyclopædia Britannica.

Benkerroum, N., Y. Bouhal, E.A. Attar and A. Marhaben (2004). Occurrence of Shiga toxin-producing E. coli $0157: \mathrm{H} 7$ in selected diary and meat products marketed in the city of Rabat, Morocco. J. Food Prot., 67 (6): 1234-1237.
Borch, E., E. Nerbrink and P. Svensson (1988). Identification of major contamination sources during processing of emulsion sausage. Int. J. Food Microbiol., 7 : 317-330.

Cheesbrough, M. (1994). District Laboratory Practice in Tropical Countries, Part 2. Cambridge Univ., 395.

Cooke, W.B. (1996) A taxonomic study in the "Black Yeasts", Mycopathol. Mycol. Applicata., 117 : 1-43.

Desrosier, N.W. and J.N. Desrosier (2004). The Technology of Foods Preservation, $4^{\text {th }}$ Ed. CBS publisher of Distributors, pvt. L.td.

Fallik, E. (2014). Microbial Quality and Safety of Fresh Produce. Postharvest Handling ( $3^{\text {rd }}$ Ed.), 313-339.

FAO/WHO (2012). Food standards programme codex committee on processed fruits and vegetables $26^{\text {th }}$ Session Montego Bay, Jamaica, 15 - 19.

Featherstone, S. (2015a). Spoilage of Canned Foods A Complete Course in Canning and Related Processes (14 ${ }^{\text {th }}$ Ed.), 27-42.

Featherstone, S. (2015b). Hazard Analysis and Critical Control Point (HACCP) Systems in Food Canning, A Complete Course in Canning and Related Processes $\left(14^{\text {th }}\right.$ Ed.), 215-234.

Freire, F.C.O. and L. Offord (2003). Bacterial and Yeasts counts in Brazilian commodities and spices. Brazilian J. Microbiol., 2 : 145148.

Garcia, L.S. (2010). Clinical Microbiology Procedures Handbook. Am. Soc. Microbiol., Washington, D.C.

Gordon-Davis, L. (1998). The Hospitality Industry Handbook on Hygiene and Safety: for South African Students and Practitioners. Juta, Kenwyn.

Holt, J.G. (1994). The Shorter Bergey's Manual of Determinative Sambrook, J. and Russell, D.W. (2001). Molecular Cloning: A Bacteriology. Willims Wilkiins, Baltimore, 356

Jay, J.M. (1992). Modern Food Microbiology. New York. 
Mosupye, F.M. and A. Von Holy (1999). Microbiological quality and safety of street vended foods in Johannesburg city, South Afr. J. Food Prot., 62: 1278-1284.

Nel, S., J.F.R. Lues, E.M. Buys and P. Venter (2004). The personal and general hygiene practices in the deboning room of a high throughput red meat abattoir. Food Control, 15: 571-578.

Nortjé G.L., L. Nel, E. Jordaan, R.T. Naudé, W.H. Holzapfel and R.J. Grimbeek (1989). A microbiological survey of fresh meat in the supermarket trade. Part 2: Beef retil cuts. Meat Sci., 25: 99-112.

Omafuvbe, B.O. and D.O. Kolawole (2004). Quality Assurance of Stored Pepper (Piper guineense) Using Controlled Processing Methods. Pak. J. Nut., 3 (4): 224-249.

Özdilli, K., H. Issever, B.A. Özyildirim, B. Hapçioglub, N. Ince, H. Ince, Y. Yegenoglu, S. Susever, M. Erelel, E. Isık and G. Gedikoglu (2007). Biological hazards in tannery workers. Indoor Built Environ., 16: 349-357.

Snedecor, G.W. and G.W. Cochran (1980). Statistical Methods, $7^{\text {th }}$ Ed. The Iowa State Univ. Press, Ames., Iowa.
Steyn, C.E., M.R. Cameron and C. Witthuhn (2011). Occurrence of Alicyclobacillus in the fruit processing environment-A review. Int. J. Food Microbiol., $147: 1-11$.

Tambekar, D.H., V.J. Jaishwal, D.V. Dhanorkar, P.B. Gullhane and M.N. Dudhane (2008). Identification of microbiological hazards and safety of ready-to-eat food vended in streets of Amravati city. India J. Appl. Biosci., 7: 195-201.

Vantarakis, A., M. Affifi, P. Kokkinos, M. Tsibouxi and M. Papapetropoulou (2011). Occurrence of microorganisms of public health and spoilage significance in fruit juices sold in retail markets in Greece Original Research Article. Anaerobe, 17 (6) : 288-291.

Zhao, Y. (2005). Pathogens in Fruit. In : Jonger, W. (Eds.), Improving the safety of fresh fruit and Vegetables. CRC Press, Washington, DC, $44-88$

Zwietering M.H., L. Jacxsens, J-M. Membr, M. Nauta and M. Peterz (2016). Review: Relevance of microbial finished product testing in food safety management. Food Control, 31-43.

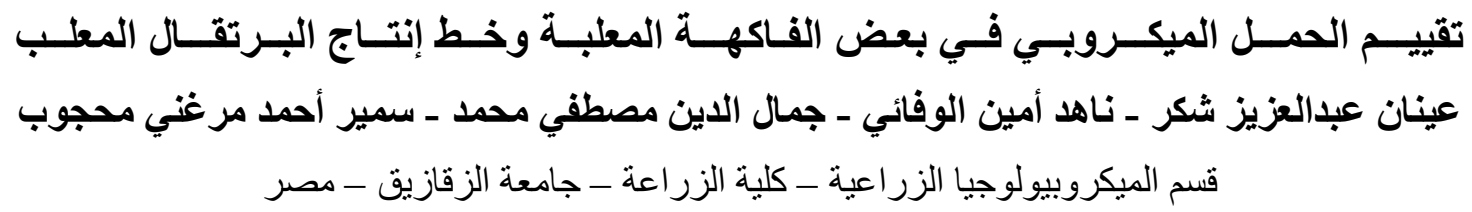

تهدف هذه الدراسة إلى تقييم الحمل الميكروبي في خط إنتاج البرتقال المعلب في مصنع محلي بالإضافة إلى إعطاء

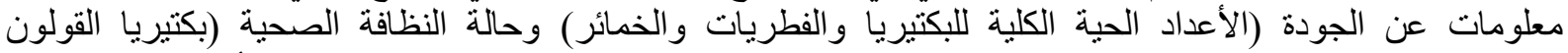

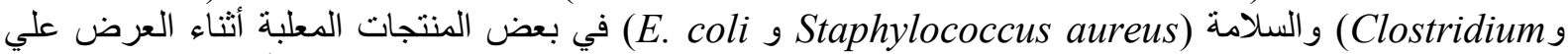

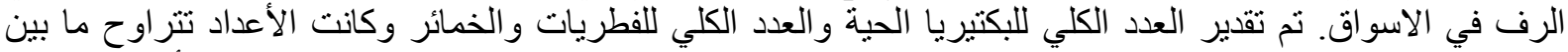

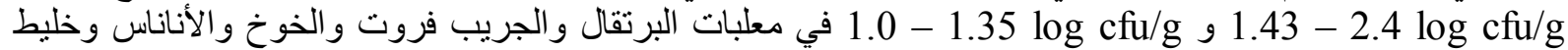

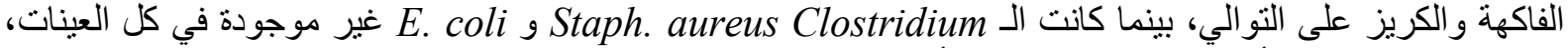

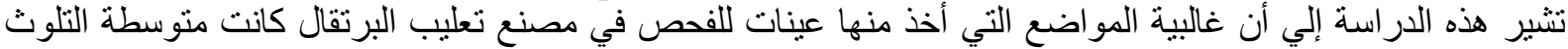
و 2.24 log cfu/g)

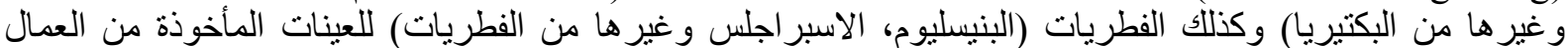

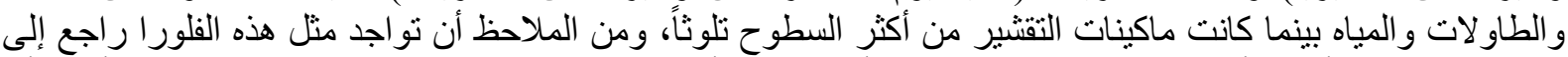

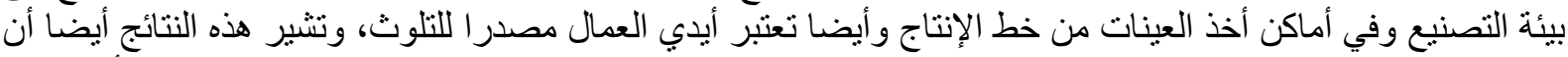

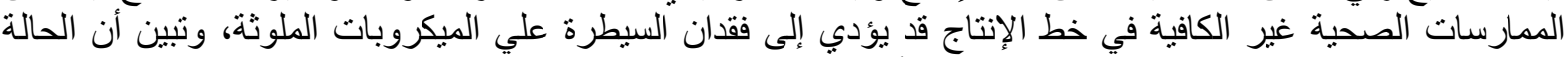

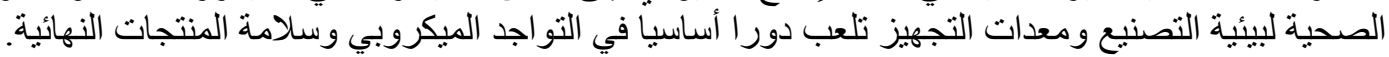

أستاذ الميكروبيولجيا الزر اعية ـ كلية الزر اعة ـ جامعة المنوفية. أستاذ ورئيس قسم الميكروبيولوجياعيا الزر اعية ـ كلية الزراعة - جامعة الزقازيقة

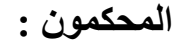

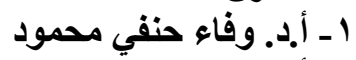

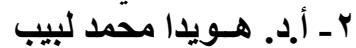

